\title{
PERSEPSI PENGUNJUNG TERHADAP WISATA ALAM DI CAMP GRANIT TAMAN NASIONAL BUKIT TIGAPULUH
}

\section{(Visitor Perception Of Nature Tourism In Camp Granit Bukit Tigapuluh National Park)}

\author{
Ave Nova Sinaga ${ }^{1}$, Defri Yoza $^{2}$, Viny Volcerina Darlis ${ }^{2}$ \\ ${ }^{1}$ Jurusan Kehutanan, Fakultas Pertanian, Universitas Riau \\ ${ }^{2}$ Dosen Jurusan Kehutanan, Fakultas Pertanian, Universitas Riau \\ Alamat, : BinaWidya, Pekanbaru, Riau
}

Email : avenovasinaga@gmail.com,defri.yoza@gmail.com,a121006viny@gmail.com,

Diterima: 21 Januari 2020, Direvisi: 03 Maret 2020, Disetujui: 20 Maret 2020

DOI: https://doi.org/10.31849/forestra

\begin{abstract}
Bukit Tiga Puluh National Park (TNBT) became a representative of lowland tropical rain forests on the island of Sumatra because it has high aesthetic value and an interesting diversity of flora and fauna, TNBT ecosystem has the potential to be developed as a natural tourist attraction. Camp Granit's nature tourism has interesting objects, both natural and artificial. The purpose of this research was to determine visitor perceptions and visitor's travel motives towards nature tourism at Camp Granit TNBT. The information were collected by field observations with an inventory of natural attractions, using a questionnaire technique. This research used quantitative descriptive methods. The results of this research showed that Camp Granit's nature tourism has a very attractive tourist environment, the level of comfort when traveling is classified as very comfortable and on the travel motives of visitors to Camp Granit nature tourism TNBT with a recreational or vacation destination of $68.60 \%$.

Keywords : Nature tourism, travel motives of visitor, visitor perception
\end{abstract}

\begin{abstract}
ABSTRAK
Taman Nasional Bukit Tiga Puluh (TNBT) menjadi perwakilan dari hutan hujan tropis dataran rendah di pulau Sumatra karena memiliki nilai estetika yang tinggi dan keanekaragaman flora dan fauna yang menarik, ekosistem TNBT berpotensi untuk dikembangkan sebagai objek wisata alam. Wisata alam Camp Granit memiliki objek-objek menarik, baik alam maupun buatan. Tujuan dari penelitian ini adalah untuk mengetahui persepsi pengunjung dan motif perjalanan pengunjung terhadap wisata alam di Camp Granit TNBT. Informasi tersebut dikumpulkan melalui observasi lapangan dengan inventarisasi atraksi alam, menggunakan teknik kuesioner. Penelitian ini menggunakan metode deskriptif kuantitatif. Hasil penelitian ini menunjukkan bahwa wisata alam Camp Granit memiliki lingkungan wisata yang sangat menarik, tingkat kenyamanan saat berpergian tergolong sangat nyaman dan pada motif perjalanan pengunjung ke wisata alam Camp Granit TNBT dengan tujuan rekreasi atau liburan sebesar $68,60 . \%$.
\end{abstract}

Kata Kunci: Wisata alam, motif perjalanan pengunjung, persepsi pengunjung 


\section{PENDAhULUAN}

Taman nasional merupakan salah satu bentuk dari kawasan pelestarian alam selain taman hutan raya dan taman wisata alam (PP Nomor 28 tahun 2011). Taman Nasional Bukit Tiga Puluh (TNBT) dianggap sebagai perwakilan hutan hujan tropis dataran rendah di Pulau Sumatera yang mempunyai nilai estetika yang tinggi dan keanekaragaman flora dan fauna yang menarik, ekosistem TNBT sangat berpotensi dikembangkan sebagai objek wisata alam. Salah satu lokasi yang memiliki potensi wisata di TNBT adalah Camp Granit.

Wisata alam di Camp Granit ini memiliki objek-objek yang sangat menarik, baik yang alami maupun artificial (buatan). Objek-objek tersebut antara lain berupa panorama alam, air terjun granit, telaga teduh, anak sungai, rumah pohon, bukit lancang, pohon mersawa dan pusat informasi. Kekayaan flora dan fauna sangat berpotensi menjadi objek daya tarik bagi para penggemar/pengunjung wisata alam. Daya tarik wisata merupakan salah satu faktor utama penggerak pariwisata pada destinasi wisata karena memotivasi wisatawan untuk mengunjungi suatu tempat
(Ismayanti, 2010). Keberadaan pengunjung dalam suatu kawasan wisata alam menjadi penilaian pada setiap langkah-langkah dalam pengelolaan. Menurut Rusita (2007), objek wisata alam yang tersebar di laut, pantai, hutan dan pegunungan adalah produk-produk potensial yang dapat dikembangkan untuk kegiatan wisata alam. Keanekaragaman hayati berupa flora dan fauna, keunikan, keindahan bentang alam serta gejala alam merupakan salah satu aspek penting yang menjadi objek dan daya tarik wisata alam (ODTWA) (Romani, 2006).

Wisata alam di Camp Granit ini dapat dikatakan memiliki prospek yang baik untuk dikembangkan menjadi salah satu destinasi wisata alam di Provinsi Riau. Wisata alam di Camp Granit ini memiliki keindahan alam yang berbeda dengan wisata lainnya, karena di dalam kawasan Camp Granit pengunjung akan merasakan indahnya alam ciptaan Tuhan, akan tetapi wisata alam di Camp Granit belum dikelola dan dikembangkan secara intensif. Oleh karena itu, perlu dilakukan studi mengenai persepsi pengunjung terhadap wisata alam di Camp Granit TNBT sebagai upayaupaya peningkatan daya tarik wisata alam 
di Camp Granit TNBT. Tujuan penelitian ini adalah untuk mengetahui persepsi pengunjung dan motif perjalanan pengunjung terhadap wisata alam di Camp Granit TNBT.

\section{METODE PENELITIAN}

Penelitian ini dilaksanakan pada bulan Februari-Maret 2019 di Zona Pemanfaatan Camp Granit Taman Nasional Bukit Tiga Puluh, Desa Talang Lakat Kecamatan Batang Gansal, Kabupaten Indragiri Hulu. Berada di wilayah kerja Resort Talang Lakat Seksi Pengelolaan Taman Nasional Wilayah II Belilas Riau. Bahan yang diperlukan selama melakukan penelitian adalah kuesioner sedangkan alat yang digunakan dalam penelitian ini adalah kamera, alat tulis dan laptop.

Pengambilan data dilakukan dengan cara observasi lapangan dengan inventarisasi objek wisata alam dan dengan teknik kuesioner. Penelitian ini menggunakan metode deskriptif kuantitatif. Teknik yang digunakan adalah accidental sampling. Dalam penelitian ini responden yang diambil ialah berumur 16 tahun keatas. Tahap selanjutnya dilakukan pengisian kuesioner yang diisi langsung oleh responden. Penentuan ukuran sampel pada penelitian ini menggunakan rumus slovin dengan batas error yang digunakan adalah 10\% (Sugiyono, 2011). Sumber sampel pengunjung di Camp Granit diambil dari data yang sudah teruji, data tersebut didapatkan dari Buku statistik Balai Taman Nasional Bukit Tiga Puluh tahun 2017. Berdasarkan data pengunjung yang ada maka pengambilan sampel menggunakan rumus slovin mendapatkan 86 responden.

Pada penelitian ini, pengambilan data primer ini diperoleh dari penyebaran kuesioner kepada responden atau pengunjung. Teknik pengumpulan data sekunder dilakukan melalui studi literatur peneliti mencari data dan informasi referensi teori yang relevan terkait wisata alam di Camp Granit TNBT serta kondisi sarana dan prasarana pendukung dari sumber tertulis atau data yang berasal dari instansi terkait. Jenis data dan pengumpulannya dapat dilihat pada tabel 1 . 
Tabel 1. Jenis Data dan Pengumpulannya

\begin{tabular}{|c|c|c|}
\hline Jenis data & Kegunaan & $\begin{array}{l}\text { Metode } \\
\text { pengump } \\
\text { ulan }\end{array}$ \\
\hline Data & & \\
\hline $\begin{array}{l}\text { Primer: } \\
\text { a. Persepsi } \\
\text { pengunj } \\
\text { ung }\end{array}$ & $\begin{array}{l}\text { Mengetahui persepsi } \\
\text { pengunjung } \\
\text { terhadap wisata } \\
\text { alam di Camp } \\
\text { Granit TNBT }\end{array}$ & $\begin{array}{l}\text { Penyebara } \\
\mathrm{n} \\
\text { kuesioner }\end{array}$ \\
\hline $\begin{array}{l}\text { Data } \\
\text { sekunder : } \\
\text { a. Sarana } \\
\text { prasaran } \\
\text { a }\end{array}$ & $\begin{array}{l}\text { Mengetahui akses } \\
\text { jalan dan prasarana } \\
\text { pendukung pada } \\
\text { wisata alam di } \\
\text { Camp Granit } \\
\text { TNBT }\end{array}$ & $\begin{array}{l}\text { Laporan } \\
\text { pengamat } \\
\text { an }\end{array}$ \\
\hline
\end{tabular}

Parameter yang diamati pada penelitian ini yaitu pengunjung yang mengunjungi wisata alam di Camp Granit TNBT yang dijadikan responden dan penyebaran kuesioner untuk memperoleh data penilaian persepsi pengunjung dalam pengembangan wisata alam di Camp Granit.

Hasil pengolahan data mengenai persepsi pengunjung wisata alam di Camp Granit tersebut kemudian diuraikan secara deskriptif. Analisis yang digunakan dalam penelitian ini ialah analisis kualitatif dengan persentase.

\section{HASIL DAN PEMBAHASAN}

\section{Gambaran Umum Lokasi Penelitian}

Camp Granit berjarak sekitar $70 \mathrm{~km}$ dari kantor Balai TNBT dengan waktu tempuh sekitar 1 jam 30 menit. Jarak menuju Camp Granit $\pm 12 \mathrm{~km}$ dan menghabiskan waktu \pm 40 menit dengan menggunakan sepeda motor dan \pm 1 jam dengan menggunakan roda empat. Administrasi Camp Granit masuk ke dalam wilayah Desa Talang Lakat Kecamatan Batang Gansal Kabupaten Indragiri Hulu Provinsi Riau. Camp Granit adalah salah satu areal di kawasan TNBT yang dimanfaatkan untuk wisata alam dengan luas \pm 23 ha atau $230.000 \mathrm{~m}^{2}$ di blok hutan Camp Granit. Selain dimanfaatkan untuk aktivitas wisata alam, Camp Granit juga berfungsi sebagai Pusat Pelatihan Penanggulangan Kebakaran Hutan (PPPKH ) yang didirikan melalui kerja sama Japan International Cooperation Agency (JICA) dan Direktorat Jenderal Perlindungan Hutan dan Kebakaran Hutan (PHKA) pada tahun 2002.

2. Potensi dan Daya Tarik Wisata Alam di Camp Granit TNBT

Menurut Perlindungan Hutan dan Konservasi Alam (PHKA) pada (2003a), daya tarik merupakan modal utama yang memungkinkan datangnya pengunjung. Potensi wisata alam yang sangat menarik adalah pemandangan alam, tumbuh- 
tumbuhan, hewan dan air terjun.

Berdasarkan hasil observasi di lapangan, wisata alam di Camp Granit TNBT memiliki objek wisata alam yang potensinya dapat dijadikan kekuatan dan daya tarik untuk menarik pengunjung dan untuk dikembangkan. Kegiatan wisata alam yang dapat dilakukan dilokasi ini adalah menikmati keindahan panorama alam, mendaki (hiking) ke Bukit Lancang, mengamati flora dan fauna, mandi Air Terjun Granit, menyusuri jalan trail wisata, dan sebagainya.

\section{Karakteristik Pengunjung Wisata Alam di Camp Granit TNBT}

Karakteristik pengunjung sangat penting diketahui untuk menentukan bentuk dan kegiatan wisata yang sesuai dengan karakter pengunjung yang datang dan diharapkan datang. Karakteristik pengunjung berdasarkan usia, pendidikan dan jenis pekerjaan dan jenis kelamin dapat dilihat pada Tabel 2.
Tabel 2. Karakteristik pengunjung wisata alam di Camp Granit TNBT berdasarkan usia, pendidikan dan jenis pekerjaan dan jenis kelamin

\begin{tabular}{|c|c|c|c|}
\hline $\mathrm{No}$ & Kategori & Jumlah responden & Persentase (\%) \\
\hline \multicolumn{4}{|c|}{ A. Usia (tahun) } \\
\hline 1. & $16-20$ & 39 & 45,35 \\
\hline 2. & $21-25$ & 26 & 30,23 \\
\hline 3. & $26-30$ & 10 & 11,63 \\
\hline 4. & $41-45$ & 5 & 5,81 \\
\hline 5. & $46-50$ & 2 & 2,33 \\
\hline 6. & $31-35$ & 2 & 2,33 \\
\hline \multirow{2}{*}{7.} & $36-40$ & 2 & 2,33 \\
\hline & Total & 86 & 100 \\
\hline \multicolumn{4}{|c|}{ B. Pendidikan } \\
\hline 1. & SMP & 32 & 37,21 \\
\hline 2. & SMA & 32 & 37,21 \\
\hline 3. & $\mathrm{SD}$ & 12 & 13,95 \\
\hline 4. & S1 & 7 & 8,14 \\
\hline \multirow{2}{*}{5.} & D3 & 3 & 3,49 \\
\hline & Total & 86 & 100 \\
\hline \multicolumn{4}{|c|}{ C. Jenis pekerjaan } \\
\hline 1. & Pelajar/mahasiswa & 44 & 51,16 \\
\hline 2. & Karyawan swasta & 20 & 23,26 \\
\hline 3. & Petani & 19 & 22,09 \\
\hline 4. & Lainnya & 2 & 2,33 \\
\hline \multirow[t]{2}{*}{5.} & Pedagang & 1 & 1,16 \\
\hline & Total & 86 & 100 \\
\hline \multicolumn{4}{|c|}{ D. Jenis kelamin } \\
\hline 1. & Laki-laki & 66 & 66,77 \\
\hline \multirow[t]{2}{*}{2.} & Perempuan & 20 & 20,23 \\
\hline & Total & 86 & 100 \\
\hline
\end{tabular}

Usia merupakan salah satu faktor pendukung untuk mengetahui kemampuan fisik responden dalam melakukan kunjungan dan produktivitas (Sihotang, 2014). Pengaruh pribadi setiap usia diduga berpengaruh terhadap keinginan untuk berkunjung ketempat wisata alam. Perbedaan usia juga akan mempengaruhi pemilihan tempat dan objek wisata. Pada penelitian ini, terdapat responden antara usia 16-20 tahun sebanyak 39 orang $(45,35 \%)$ dengan tingkat pendidikan SMP $(37,21 \%)$ dan SMA $(37,21 \%)$, dengan begitu mereka berstatus sebagai pelajar sebanyak 44 orang $(51,16 \%)$ yang paling 
banyak mengunjungi wisata alam di Camp

Granit TNBT hal ini dikarenakan anak muda mempunyai jiwa berpetualang yang tinggi, mempunyai fisik yang kuat dan aktif mencari pengalaman yang berbeda melalui traveling dan selalu ingin merasakan pengalaman menjelajahi tempat baru.

Karakteristik kunjungan terdiri dari waktu kunjungan yang dipilih untuk melakukan kegiatan berwisata, frekuensi kunjungan, siapa yang berperan dalam pengambil keputusan berkunjung dan bentuk perjalanan wisata yang dilakukan (diri sendiri, bersama teman, keluarga dan lain-lain). Dapat dilihat pada tabel 3.

Tabel 3. Karakteristik kunjungan wisata alam di Camp Granit TNBT

\begin{tabular}{|c|c|c|c|}
\hline No. & Kategori & Jumlah responden & Persentase (\%) \\
\hline A. & Waktu berkunjung & & \\
\hline 1. & Akhir pekan & 61 & 70,93 \\
\hline 2. & Hari kerja & 13 & 15,12 \\
\hline 3. & Hari libur nasional & 5 & 5,81 \\
\hline \multirow[t]{2}{*}{4.} & Lainnya & 7 & 8,14 \\
\hline & Total & 86 & 100 \\
\hline B. & Frekuensi kunjungan & & \\
\hline 1 . & Pertama kali & 28 & 32,56 \\
\hline 2. & $2 \mathrm{kali}$ & 21 & 24,42 \\
\hline 3. & 3 kali & 17 & 19,76 \\
\hline 4. & 5 kali & 6 & 6,98 \\
\hline \multirow[t]{2}{*}{4.} & Lebih dari 5 kali & 14 & 16,28 \\
\hline & Total & 86 & 100 \\
\hline C. & Pola kunjungan & & \\
\hline 1. & Teman-teman & 70 & 81.40 \\
\hline 2. & Kelompok wisata & 11 & 12,79 \\
\hline 3. & Keluarga & 4 & 4,65 \\
\hline 4. & Sendiri & 1 & 1,16 \\
\hline \multirow[t]{2}{*}{5.} & Lainnya & 0 & 0,00 \\
\hline & Total & 86 & 100 \\
\hline D. & Sifat kunjungan & & \\
\hline 1. & Memperluas wawasan & 44 & 51,16 \\
\hline 2 . & Mencari inspirasi baru & 22 & 25,58 \\
\hline 3. & Menyalurkan hobi & 11 & 12,79 \\
\hline 4. & Menghilangkan lelah setelah bekerja & 9 & 10,47 \\
\hline \multirow[t]{2}{*}{5.} & Lainnya & 0 & 0,00 \\
\hline & & 86 & 100 \\
\hline \multicolumn{4}{|c|}{ Lama waktu berkunjung } \\
\hline 1. & $1 \mathrm{jam}$ & 5 & 5,81 \\
\hline 2. & $2-4 \mathrm{jam}$ & 21 & 24,42 \\
\hline 3. & $5-8 \mathrm{jam}$ & 23 & 26,74 \\
\hline 4. & $9-12 \mathrm{jam}$ & 28 & 32,56 \\
\hline \multirow[t]{2}{*}{5.} & Lainnya & 9 & 10,47 \\
\hline & Total & 86 & 100 \\
\hline
\end{tabular}

Pada tabel 3 menunjukkan sebagian besar responden memilih waktu kunjungan pada akhir pekan sebanyak 61 orang (70,93\%) untuk berkunjung ke wisata alam di Camp Granit TNBT. Hal ini disebabkan karena adanya kegiatan bersekolah yang harus diikuti pada hari senin sampai jumat dan baru bisa melakukan wisata pada akhir pekan yaitu hari sabtu dan minggu. Pemilihan waktu wisata pada akhir pekan merupakan waktu yang tepat untuk berwisata bersama anggota keluarga dan teman-teman.

Pengunjung mendapat informasi keberadaan wisata alam di Camp Granit TNBT dari informasi lisan yakni sebesar $69,77 \%$ didominasi oleh mereka yang berasal dari dalam Kabupaten Indragiri Hulu yakni sebesar 74,42\%, sedangkan persentase menggunakan transportasi sendiri yakni sebesar $97,67 \%$ dan pada persentase mengeluarkan biaya wisata tergolong murah yakni sebesar 39,53\% dengan menghabiskan waktu sekitar 30 menit-1 jam perjalanan yakni sebesar 44,18\% yang dapat dilihat pada Tabel 4 sebagai berikut. 
Tabel 4. Sumber Informasi, Asal Responden, Alat Transportasi, Biaya dan Lama Perjalanan Wisata Alam di Camp Granit TNBT

\begin{tabular}{|c|c|c|c|}
\hline No. & Kategori & Jumlah responden & Persentase (\%) \\
\hline A. & Sumber informasi & & \\
\hline 1. & Informasilisan & 60 & 69,77 \\
\hline 2. & Media elektronile & 14 & 16,28 \\
\hline 3. & Media cetak & 4 & 4,65 \\
\hline 4. & Biro perjalanan wisata & 3 & 3,49 \\
\hline 5. & Lainnya & 5 & 5,81 \\
\hline$B_{B}$ & $\begin{array}{l}\text { Total } \\
\text { Assal responden }\end{array}$ & 86 & 100 \\
\hline 1. & Dalam kabupaten & 64 & 74,42 \\
\hline 2 & Luar kabupaten & 9 & 10.46 \\
\hline 3. & Luar provinsi & 13 & 15,12 \\
\hline & Total & 86 & 100 \\
\hline $\begin{array}{l}\text { C. } \\
1 .\end{array}$ & $\begin{array}{l}\text { Transportasidigunakan } \\
\text { Anglutan pribadi }\end{array}$ & 84 & 97,67 \\
\hline 3. & $\begin{array}{l}\text { Angkutan umum } \\
\text { Bus }\end{array}$ & $\stackrel{0}{0}$ & $\begin{array}{l}0,00 \\
0,00\end{array}$ \\
\hline 4. & Lainnya & 2 & 2,33 \\
\hline D. & $\begin{array}{l}\text { Total } \\
\text { Biaya wisata }\end{array}$ & & 100 \\
\hline 1. & Sangat murah & 18 & 20,93 \\
\hline 2. & Murah & 34 & 39,53 \\
\hline & Cukup & 32 & 37,21 \\
\hline & $\begin{array}{l}\text { Mahal } \\
\text { Sangat mahal }\end{array}$ & & 1,16 \\
\hline 5. & $\begin{array}{l}\text { Sangat mahal } \\
\text { Total }\end{array}$ & $\begin{array}{l}1 \\
86\end{array}$ & $\begin{array}{l}1,16 \\
100\end{array}$ \\
\hline E. & Lama perjalanan & & \\
\hline$\frac{1}{2}$. & $\begin{array}{l}30 \text { menit- } 1 \text { jam } \\
2-5 \text { jam }\end{array}$ & $\begin{array}{l}38 \\
25\end{array}$ & $\begin{array}{l}44,18 \\
29,07\end{array}$ \\
\hline & $\begin{array}{l}1-2 \text { jam } \\
1 \text { am }\end{array}$ & 20 & 23,26 \\
\hline & $\begin{array}{l}\text { Lainnya } \\
\text { Total }\end{array}$ & $\begin{array}{l}3 \\
86\end{array}$ & $\begin{array}{l}3,49 \\
100\end{array}$ \\
\hline
\end{tabular}

Sebagian besar pengunjung mengetahui keberadaan wisata alam di Camp Granit TNBT dari informasi lisan yaitu sebanyak $69,77 \%$ dari teman, saudara maupun keluarga yang sudah pernah mengunjungi Camp Granit yang merasa puas dengan wisata di Camp Ganit, lalu menceritakan pengalamannya kembali kepada orang lain yang dapat mempengaruhi wisatawan untuk berkunjung. Hal ini diduga karena teman sebagai sumber informasi yang paling dipercaya dalam mendapatkan informasi, pengalaman yang telah didapatkan teman yang telah melakukan kunjungan dapat dijadikan acuan untuk memilih tempat wisata.
4. Persepsi Pengunjung terhadap Wisata Alam di Camp Granit TNBT

Persepsi seringkali diartikan dengan pendapat, sikap dan penilaian. Persepsi merupakan suatu proses yang didahului oleh penginderaan dengan proses yang berujung ke pusat susunan saraf yaitu otak hingga individu tersebut mengalami persepsi (Walgito, 1997). Persepsi pengunjung merupakan salah satu hal yang penting dalam pengembangan suatu destinasi wisata. Mengenai apa yang diminati, diinginkan dan diharapkan oleh pegunjung ke suatu destinasi menjadi amat penting artinya dalam kaitan dengan pemasaran objek wisata (Warpani, 2007).

\section{a. Persepsi Pengunjung terhadap}

\section{Objek dan Daya Tarik Wisata}

Perkembangan suatu kawasan wisata juga tergantung pada apa yang dimiliki kawasan tersebut untuk dapat ditawarkan kepada wisatawan. Hal ini tidak dapat dipisahkan dari peranan para pengelola kawasan wisata. Menurut pendapat yang dikemukakan oleh Yoeti (1991) bahwa berhasilnya suatu tempat wisata hingga tercapainya industri wisata sangat tergantung pada $3 \mathrm{~A}$ yaitu atraksi 
(attraction) mudah dicapai (accesibility), dan fasilitas (amenities).

Objek dan daa tarik wisata merupakan dasar bagi kepariwisataan. Tanpa adanya daya tarik di suatu daerah atau tempat tertentu sulit untuk dikembangkan. Berikut persepsi pengunjung terhadap objek dan daya tarik wisata alam di Camp Granit TNBT dapat dilihat pada tabel 5.

Tabel 5. Persepsi Pengunjung Terhadap Daya Tarik Lingkungan Wisata

\begin{tabular}{|c|c|c|c|c|}
\hline No. & Kategori & $\begin{array}{c}\text { Kategori } \\
\text { jawaban }\end{array}$ & $\begin{array}{c}\text { Frekuensi } \\
\text { jawaban }\end{array}$ & $\begin{array}{c}\text { Persentase } \\
(\%)\end{array}$ \\
\hline \multirow[t]{5}{*}{1.} & Pemandangan alam & Sangat menarik & 58 & \\
\hline & & Menarik & 18 & 20,93 \\
\hline & & Cukup menarik & 9 & 10,47 \\
\hline & & Kurang menarik & 1 & 1,16 \\
\hline & & Tidak menarik & 0 & 0,00 \\
\hline \multirow[t]{5}{*}{2.} & Tumbuh-tumbuhan & Sangat menarik & 34 & 39,53 \\
\hline & & Menarik & 30 & 34,88 \\
\hline & & Cukup menarik & 20 & 23,26 \\
\hline & & Kurang menarik & 2 & 2,33 \\
\hline & & Tidak menarik & 0 & 0,00 \\
\hline \multirow[t]{5}{*}{3.} & Hewan & Sangat menarik & 27 & 31,39 \\
\hline & & Menarik & 25 & 29,07 \\
\hline & & Cukup menarik & 20 & 23,26 \\
\hline & & Kurang menarik & 12 & 13,95 \\
\hline & & Tidak menarik & 2 & 2,33 \\
\hline \multirow[t]{5}{*}{4.} & Air terjun & Sangat menarik & 49 & 56,98 \\
\hline & & Menarik & 22 & 25,58 \\
\hline & & Cukup menarik & 9 & 10,47 \\
\hline & & Kurang menarik & 5 & 5,81 \\
\hline & & Tidak menarik & 1 & 1,16 \\
\hline \multirow[t]{5}{*}{5.} & Pusat penelitian & Sangat menarik & 26 & 30,23 \\
\hline & & Menarik & 30 & 34,88 \\
\hline & & Cukup menarik & 27 & 31,40 \\
\hline & & Kurang menarik & 3 & 3,49 \\
\hline & & Tidak menarik & 0 & 0,00 \\
\hline \multirow[t]{5}{*}{6.} & Jalan setapal/ jembatan & Sangat menarik & 9 & 10,47 \\
\hline & & Menarik & 21 & 24,42 \\
\hline & & Cukup menarik & 12 & 13,95 \\
\hline & & Kurang menarik & 28 & 32,56 \\
\hline & & Tidak menarik & 16 & 18,60 \\
\hline
\end{tabular}

Pada Tabel 5 dapat dilihat bahwa pemandangan alam, tumbuh-tumbuhan, hewan dan air terjun tergolong sangat menarik hal itu dikarenakan pengunjung sangat menikmatinya dan merupakan faktor penarik wisatawan berkunjung ke wisata alam di Camp Granit TNBT. Objek daya tarik wisata alam di Camp Granit TNBT bersifat in-situ (di dalam kawasan). Objek ekowisata in-situ mempunyai keterkaitan yang kuat antara habitat dan ekosistem alaminya (Tuwo, 2011). Pusat penelitian masih tergolong menarik dan jalan setapak/jembatan tergolong kurang menarik hal itu karena kondisinya yang belum memadai sehingga belum bisa digunakan dengan semestinya.

\section{b. Persepsi Pengunjung terhadap \\ Kegiatan Wisata \\ Pada saat berwisata tingkat kenyamanan sangatlah penting.} Kenyamanan pengunjung dalam berwisata menjadi pertimbangan besar dalam mengembangkan areal untuk destinasi wisata. Pengelola ekowisata menempatkan perhatian serius terhadap kenyamanan pengunjung dalam berwisata (Moscardo, 1998). Persepsi pengunjung terhadap tingkat kenyamanan dalam berwisata di Camp Granit TNBT dapat dilihat pada tabel 6. 
Tabel 6. Persepsi Pengunjung Terhadap \ Tingkat Kenyamanan Dalam Berwisata di Camp Granit TNBT

\begin{tabular}{|c|c|c|c|c|}
\hline \multirow[t]{2}{*}{ No. } & \multirow[t]{2}{*}{ Kategori } & \multicolumn{3}{|c|}{ Jawaban responden dan persentase } \\
\hline & & KJ & FJ & $(\%)$ \\
\hline \multirow[t]{5}{*}{1.} & \multirow{5}{*}{$\begin{array}{l}\text { Menikmati pemandangan } \\
\text { alam }\end{array}$} & Sangat nyaman & 50 & 58,14 \\
\hline & & Nyaman & 28 & 32,56 \\
\hline & & Cukup nyaman & 8 & 9,30 \\
\hline & & Kurang nyaman & 0 & 0,00 \\
\hline & & Tidak nyaman & 0 & 0,00 \\
\hline \multirow[t]{5}{*}{2.} & \multirow{5}{*}{$\begin{array}{l}\text { Mengamati hewan/ } \\
\text { tumbuhan }\end{array}$} & Sangat nyaman & 19 & 22,09 \\
\hline & & Nyaman & 40 & 46,51 \\
\hline & & Cukup nyaman & 19 & 22,09 \\
\hline & & Kurang nyaman & 8 & 9,30 \\
\hline & & Tidak nyaman & 0 & 0,00 \\
\hline \multirow[t]{5}{*}{3.} & \multirow[t]{5}{*}{ Menelusuri jalan setapak } & Sangat nyaman & 14 & 16,28 \\
\hline & & Nyaman & 16 & 18,60 \\
\hline & & Cukup nyaman & 32 & 37,21 \\
\hline & & Kurang nyaman & 19 & 22,09 \\
\hline & & Tidak nyaman & 5 & 5,81 \\
\hline \multirow[t]{5}{*}{4.} & \multirow[t]{5}{*}{ Menelusuri track wisata } & Sangat nyaman & 16 & 18,60 \\
\hline & & Nyaman & 35 & 40,70 \\
\hline & & Cukup nyaman & 24 & 27,91 \\
\hline & & Kurang nyaman & 10 & 11,63 \\
\hline & & Tidak nyaman & 1 & 1,16 \\
\hline
\end{tabular}

Penilaian responden pengunjung menyatakan bahwa responden merasakan sangat nyaman pada saat menikmati pemandangan alam, merasa nyaman pada saat mengamati hewan dan menelusuri track wisata namun pada saat menelusuri jalan setapak pengunjung merasa cukup nyaman hal ini dikarenakan kondisi fisik jalan setapak/jembatan yang rusak atau belum memadai. Kenyamanan dalam berwisata sangat dibutuhkan oleh pengunjung.

\section{Motif Perjalanan Wisata}

Motivasi pengunjung terhadap objek wisata sangat berkaitan erat, karena objek wisata dikelola untuk dapat memenuhi keinginan atau motivasi pengunjung untuk menikmati wisata dan melepaskan penat.
Menurut Jayapalan (2001) mengungkapkan bahwa seseorang termotivasi melakukan perjalanan antara lain faktor fisik seperti melakukan perjalanan wisata karena adanya kebutuhan dari wisatawan untuk relaksasi dari rutinitas kerja. Adapaun tujuan berkunjung ke wisata alam di Camp Granit TNBT disajikan pada Tabel 7.

Tabel 7. Tujuan Berkunjung Ke Wisata Alamdi Camp Granit TNBT

\begin{tabular}{lcc}
\hline \multicolumn{1}{c}{ Kategori } & $\begin{array}{c}\text { Jumlah } \\
\text { responden }\end{array}$ & $\begin{array}{c}\text { Persentase } \\
(\%)\end{array}$ \\
\hline $\begin{array}{l}\text { 1. Tujuan berkunjun } \varepsilon \\
\text { a. Rekreasi/liburan }\end{array}$ & 59 & 68,60 \\
b. & & \\
Penelitian/pendidikar & 20 & 23,26 \\
c. Track wisata & 6 & 6,98 \\
d. Ritual/budaya & 0 & 0,00 \\
e. Lainnya & 1 & 1,16 \\
\multicolumn{1}{c}{ Total } & 86 & 100 \\
\hline
\end{tabular}

Wisata alam di Camp Granit TNBT mempunyai pemandangan lepas yang sangat asri dan nyaman sehingga menarik minat pengunjung untuk berekreasi menikmati alam. Pengunjung semacam ini banyak ditemui di lokasi dan sangat mendominasi motivasi kunjungan yakni sebesar 68,60\%. Menurut Spillane (1987), pariwisata untuk rekreasi dilakukan oleh orang-orang yang menghendaki pemanfaatan hari-hari liburnya untuk 
beristirahat, untuk memulihkan kembali kesegaran jasmani dan rohaninya.

\section{KESIMPULAN DAN SARAN}

\section{A. Kesimpulan}

Dari hasil penelitian yang telah dilaksanakan dapat disimpulkan bahwa :

1. Persepsi pengunjung terhadap wisata alam Camp Granit TNBT memiliki daya tarik lingkungan wisata tergolong sangat menarik, tingkat kenyamanan pada saat berwisata tergolong sangat nyaman.

2. Motif perjalanan pengunjung terhadap wisata alam di Camp Granit TNBT dengan tujuan rekreasi atau liburan sebesar $68,60 \%$.

\section{B. Saran}

Perlu adanya penelitian lanjutan tentang peran serta masyarakat dalam upaya pengembangan wisata alam di Camp Granit TNBT.

\section{DAFTAR PUSTAKA}

Direktorat Jenderal Perlindungan Hutan dan Konservasi Alam. 2003. Pedoman Analisis Daerah Operasi Objek dan
Daya Tarik Wisata Alam (ADOODTWA). Jakarta. Direktorat Jenderal Perlindungan Hutan dan Konservasi Alam.

Ismayanti. 2010. Pengantar Pariwisata. Grasindo. Jakarta.

Jayapalan, N. 2001. An Introduction to Tourism. Atlantic Publisher and Distributor. B, Vishal Enelave. New Delhi.

Moscardo, G. 1998.Interpretation and sustainable tourism: functions, examples and principles. The Journal of Tourism Studies.

Pemertintah Republik Indonesia. 2011. Peraturan Pemerintah Republik Indonesia Nomor 28 Tahun 2011 tentang PengelolaanKawasan Suaka Alam dan Kawasan Pelestarian Alam. Pemertintah Republik Indonesia. Jakarta.

Romani, S. 2006. Penilaian Potensi Objek dan Daya Tarik Wisata Alam serta Alternatif Perencanaannya di Taman Nasional Bukit Duabelas Provinsi Jambi. Skripsi. IPB. Bogor.

Rusita. 2007. Studi Pengembangan Produk Wisata Alam di Kawasan Taman Nasional Gunung Palung Kalimantan Barat. Tesis. Universitas Gadjah Mada. Yogyakarta.

Sugiyono. 2010. Metode Penelitian Kuantitatif, Kualitatif. Alfabeta. Bandung. 
Spillane J.J. 1987. Pariwisata Indonesia. Sejarah dan Prospeknya. Kanisiua. Yogyakarta.

Tuwo, A. 2011. Wijaya, A (Editor). Pengelolaan Ekowisata Pesisir dan Laut Pendekatan Ekologi, SosialEkonomi, Kelembagaan, dan Sarana Wilayah. Penerbit Brilian Internasional. Surabaya.

Warpani. 2007. Pariwisata dalam Tata Ruang Wilayah. ITB. Bandung.

Walgito, B. 1997. Pengantar Psikologi Umum. Andi Offset. Yogyakarta.

Yoeti, O. 1991. Pengantar Ilmu Pariwisata. Angkasa. Bandung. 